\title{
Soil fertility effect on water productivity of maize in the upper blue nile basin, Ethiopia
}

\author{
Teklu Erkossa*, Seleshi Bekele Awulachew, Denekew Aster \\ International Water Management Institute, Addis Ababa, Ethiopia; ${ }^{*}$ Corresponding Author: t.erkossa@cgiar.org
}

Received 1 July 2011; revised 28 July 2011; accepted 5 August 2011.

\begin{abstract}
Maize (Zea mays) is among the major cereals grown in the high rainfall areas of the subSaharan Africa's (SSA) such as the Ethiopian part of the Blue Nile basin. However, its productivity is severely constrained by poor soil, water and crop management practices. This study simulated water productivity of the crop under varying soil fertility scenarios (poor, near optimal and non limiting) using hybrid seeds under rainfed conditions using the FAO AquaCrop model. The result indicated that grain yield of maize increased from 2.5 tons $\cdot \mathrm{ha}^{-1}$ under poor to 6.4 and 9.2 tons $\cdot \mathrm{ha}^{-1}$ with near optimal and non-limiting soil fertility conditions. Correspondingly, soil evaporation decreased from 446 $\mathrm{mm}$ to 285 and $204 \mathrm{~mm}$, while transpiration increased from 146 to 268 and $355 \mathrm{~mm}$. Consequently, grain water productivity was increased by $48 \%$ and $54 \%$, respectively, with the near optimal and non-limiting soil fertility conditions. The water productivity gain mainly comes from reduced evaporation and increased transpiration without significantly affecting water left for downstream ecosystem services. Therefore, this has a huge implication for a basin scale water management planning for various purposes.
\end{abstract}

Keywords: AquaCrop; Simulation; Water Productivity; Soil Fertility; Nitisols

\section{INTRODUCTION}

Agricultural water management for food and livelihood security is a major concern in the face of persistent poverty and rampant environmental degradation in the Sub Saharan Africa (SSA). About $97 \%$ of agricultural land in SSA is under rainfed system [1], which will remain the dominant source of food production in the near future [2]. However, crop yield from rainfed agriculture in the region remains meager (around $1 \mathrm{t}^{\cdot h a^{-1}}$ ) [3]. This suboptimal performance is due to management problems rather than low potential of the agro-ecosystem $[4,5]$. In the tropical environment, various abiotic and biotic factors including climatic conditions such as temperature, rainfall, season length and fertility affect crop productivity [6]. There are evidences showing that rainfed agriculture generates among the world's highest yields in several regions of the world [7]. Yields in commercial rainfed agriculture in the sub-humid and humid tropical regions may exceed $5-6$ tons $\cdot \mathrm{ha}^{-1}$ [5]). However, due to the widespread nutrient depletion in agricultural soils exacerbated by improper land use, yield and water productivity in the rainfed systems in many SSA countries is decreasing or stagnating [7]. Drechsel [8] suggests that nutrient depletion is the chief biophysical factor limiting small-scale production in Africa.

In the upper part of the Blue Nile basin, sever land degradation, exacerbated by lack of external inputs such as improved seeds and fertilizers lead to low agricultural productivity. Hitherto, expansion of cultivated land has been the major strategy to cope with the low productivity, population expansion and increased demand for food. However, this strategy is challenged as the agriculturally suitable lands are almost used up, especially in the highlands. Therefore, technological interventions are indispensable to overcome the biophysical constraints and enhance land and water productivity in the area.

With its total annual production and productivity exceeding all other cereals (23.24\% of 13.7 Million tons), and second after tef (Eragrostis tef) in area coverage (16.12\% of the 8.7 million hectares), maize (Zea mays) is one of the most important crops grown in Ethiopia [9]; [10]. It is the most extensively cultivated food crops and main source of calorie in the Ethiopian part of the Blue Nile basin [11]. With the introduction of the hybrid seeds and the high yielding open pollinated varieties, and the increasing local demand, the importance of the crop may increase even further. However, the current national av- 
erage yield is about 2 tons $\cdot \mathrm{ha}^{-1}$ [10], which is much lower than its productivity in industrialized countries such as USA ( 8 - 9 tons $\left.\cdot \mathrm{ha}^{-1}\right)$ [12], the developing worlds' average $\left(3\right.$ tons $\left.\cdot \mathrm{ha}^{-1}\right)$ and the yield recorded under demonstration plots in Ethiopia (5 - 6 tons ha ${ }^{-1}$ ) [9].

According to Tanner and Sinclair [13], in situations where yield is less than $40 \%-50 \%$ of potential, nonwater factors such as soil fertility limit yield and crop water productivity per unit of evapotranspiration. In the Ethiopian part of the Blue Nile basin, land degradation and nutrient depletion, lack of access to improved technologies such as seeds and fertilizers, and poor weed and pest control practices are among the major factors depressing the water productivity of maize [11]. At the basin scale, water is a scarce resource, which should be utilized efficiently. This is becoming pressing issue with the looming effects of climate change, increased water demand due to population growth and economic development.

The idea of producing more with less water led to the evolution of the concept of water productivity (WP), which is a robust measure to assess the ability of agricultural systems to convert water into food and other useful products [14]. Agricultural WP is defined as the ratio of the net benefits from crop, forestry, fishery, and livestock to the amount of water required to produce those benefits [15]. Crop WP is the physical mass of production or its economic value measured against gross inflows, net inflow, depleted water, process depleted water, or available water $[15,16]$. Crop WP can be enhanced by increasing the yield per unit area of land by using better agronomic practices and improved crop varieties. This study assessed the effects of soil fertility levels on water productivity of maize and the water balance of the maize based farming system in the Ethiopian part of the Blue Nile basin.

\section{MATERIALS AND METHODS}

\subsection{Location and Biophysical Settings}

The study was conducted in the Abbay river basin, which is situated in the north-central and western parts of Ethiopia. The basin is situated in the upper part of the Blue Nile Basin and is one of the three major sub-basins of the Nile basin draining from Ethiopia (Figure 1). High bio- physical variability (elevation, slope, climate and soil type) characterizes the basin. However, only four soil types including Nitisols, Leptosols, Luvisols and Vertisols cover over $80 \%$ of the area [17]. In response to the biophysical variability, diverse farming systems have evolved but covering $23 \%$ of the area, the maize based farming system is the second largest after the tef based system (Figure 2). Maize is widely grown also in other farming systems in the basin as the second or third crop. The study focused on the Nitisols area, which covers about $70 \%$ of the 4.4 million hectares of the maize based farming systems.

\subsection{The Maize Based Farming System}

Maize is the dominant crop in this farming system, which is situated in the southwestern part of the Abbay Basin, but a number of other crops like tef, wheat (Triticum durum Desf.), barley (Hordeum Vulgare), and finger millet (Eleusine coracana) pulses, oil crops and vegetables like potatoes (Colcus edulis) are also widely grown as the second or third crop depending on the local circumstances. In addition, root and tuber crops are grown with some fruit trees like citrus, mango (Magnifera indica) and banana (Musa acuminate). Although nutrient depletion through soil erosion by water and crop uptake is prevalent, not many farmers use the optimal type and quantity of fertilizers. The use of manure as fertilizer is restricted to backyards [19]. In addition, the use of improved seeds is minimal.

\subsection{Analytical Tool and Data Capturing}

The FAO Aqua Crop model Version 3 [21,22] was used to simulate the grain and biomass productivity of maize as well as the water balance of the farming system. The climatic, soil characteristics (rooting depth, texture and hydraulic characteristics) and crop variables were the inputs to the model. The model was validated using daily weather and crop data obtained from research centers located within or just at the boundary of the basin (Table 1). For simulation, ten years monthly average rainfall, minimum and maximum temperature, relative humidity, dew point temperature, wind speed at $2 \mathrm{~m}$ above the ground, bright sunshine hours and radiation data obtained from the National Meteorological Services Agency (NMSA) were used. The Reference Evapotranspiration (ETo) for both the validation and simulation phases was estimated using the ETo Calculator [21], based on daily minimum and maximum temperature and wind speed data obtained from the weather stations. The average atmospheric $\mathrm{CO}_{2}$ concentration (369.41 ppm by volume) measured for the year 2000 at Mauna Loa Observatory in Hawai [21] was used as a reference default value. Soil profile data from the agricultural research centers [23,24] and basin master plan study [25], were used for the validation and simulation phases, respectively. 


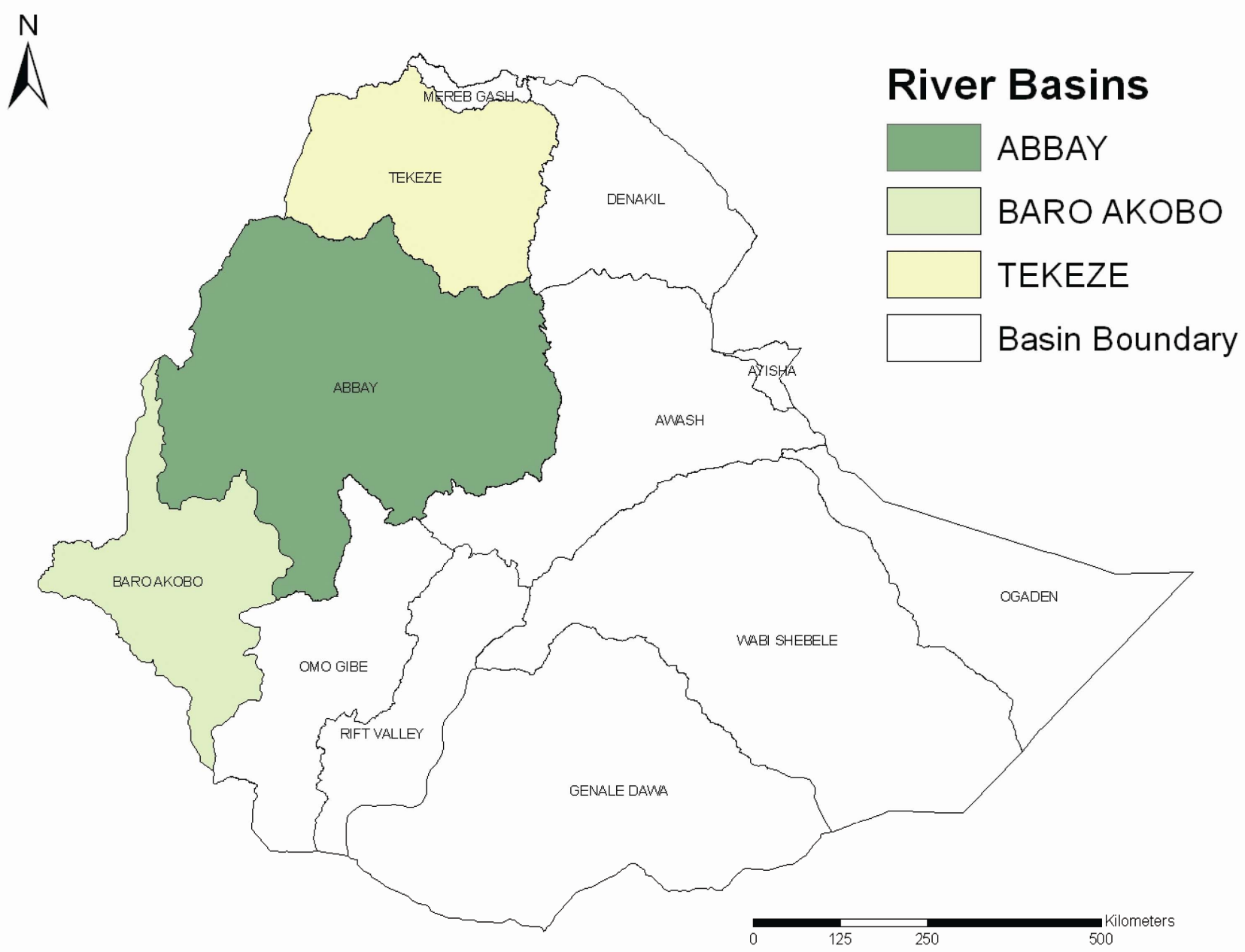

Figure 1. The three sub-basins of the Ethiopian Nile basin. Source: [18].

Table 1. Location of the research stations used for model validation.

\begin{tabular}{cccc}
\hline Location & Latitude & Longitude & Altitude (m·asl) \\
\hline Adet & $11^{\circ} 16^{\prime} \mathrm{N}$ & $37^{\circ} 28^{\prime} \mathrm{E}$ & 2080 \\
Ambo & $8^{\circ} 58^{\prime} \mathrm{N}$ & $37^{\circ} 52^{\prime} \mathrm{E}$ & 2130 \\
Bako & $9^{\circ} 06^{\prime} \mathrm{N}$ & $37^{\circ} 09^{\prime} \mathrm{E}$ & 1650 \\
Fogera & $11^{\circ} 55^{\prime} \mathrm{N}$ & $37^{\circ} 41^{\prime} \mathrm{E}$ & 1810 \\
Pawe & $11^{\circ} 14^{\prime} \mathrm{N}$ & $36^{\circ} 03^{\prime} \mathrm{E}$ & 1050 \\
\hline
\end{tabular}

\subsubsection{Description of the Model}

AquaCrop was developed to replace the approach developed by Doorenbos and Kassam [29] (FAO Irrigation $\&$ Drainage Paper no. 33) to determine the yield response to water for field, vegetable and tree crops [21, 22]. Among the significant departures of the model from its precursors is that it separates 1) the ET into soil evaporation (E) and crop transpiration (T) and 2) the final yield $(\mathrm{Y})$ into biomass $(\mathrm{B})$ and harvest index $(\mathrm{HI})$ [22]. The separation of ET into E and T avoids the con- founding effect of the non-productive consumptive use of water (E) while the separation of Y into B and $\mathrm{HI}$ allows the distinction of the functional relations between the environment and $\mathrm{B}$ from those between environment and HI. The use of this relation (Equation 1) avoids the confounding effects of water stress on B and on $\mathrm{HI}$.

$$
\mathrm{B}=\mathrm{WP} \times \sum \mathrm{T}
$$

where:

$\mathrm{T}$ is the crop transpiration (mm) and WP is the water productivity parameter $\left(\mathrm{kg}\right.$ of biomass $\mathrm{m}^{-2}$ and per $\mathrm{mm}$ of cumulated water transpired over the period in which the biomass is produced).

In addition, the model performs a daily water balance that includes all the incoming and outgoing water fluxes (infiltration, runoff, deep percolation, evaporation and transpiration) and changes in soil water content [27].

\subsubsection{Calibration of the Model}

The model has been parameterized and tested for 


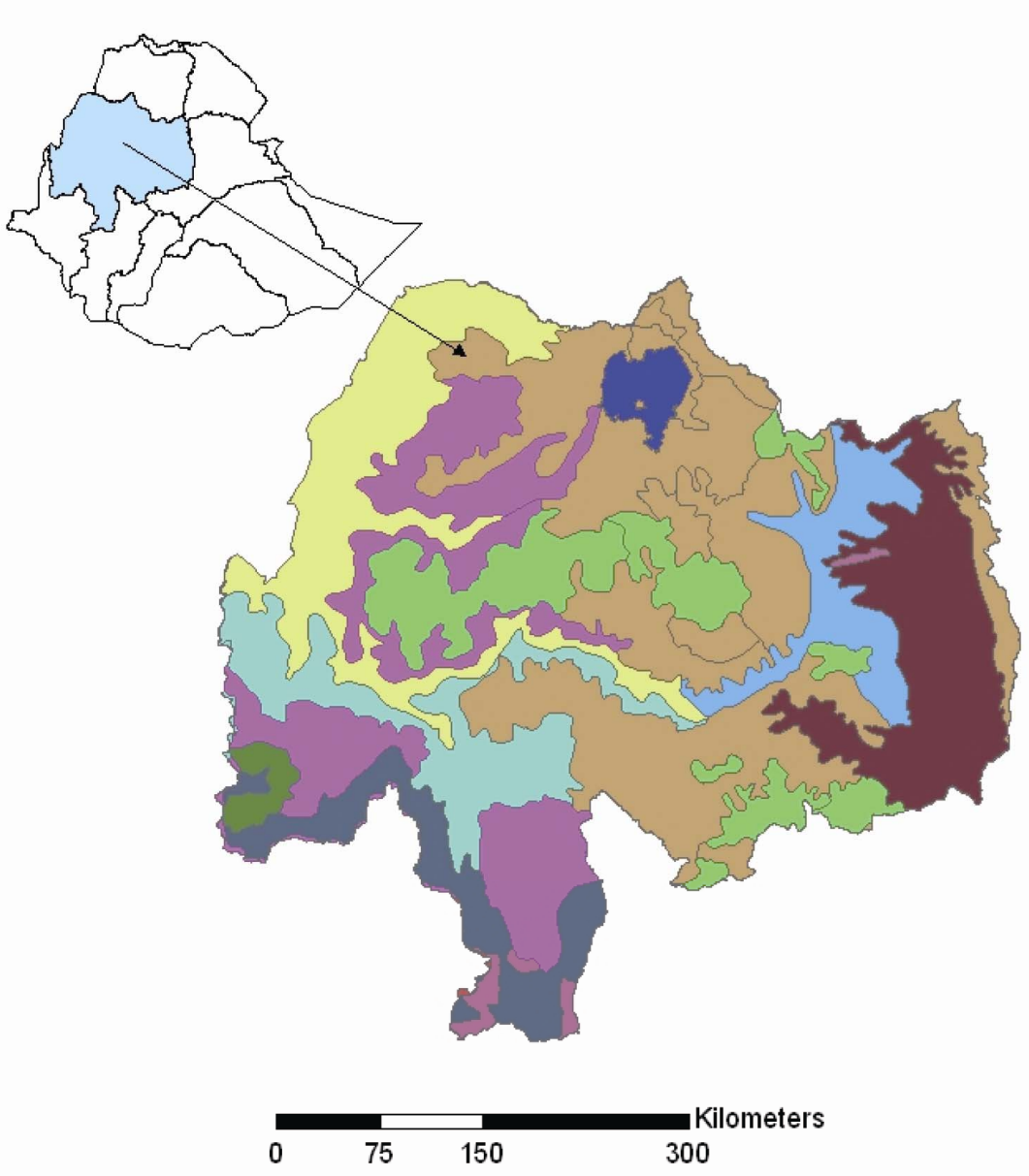

\begin{tabular}{|l}
\hline Farming System \\
Barley based double cropping \\
\hline Barley based single cropping \\
Coffee-maize complex \\
Enset root crops complex \\
Forest \\
\hline$\quad$ Maize based shifting cultivation \\
Maize based single cropping \\
Not suitable \\
\hline Sorghum based shifting cultivation \\
\hline Sorghum based single cropping \\
\hline Tef based single cropping \\
Water body
\end{tabular}

Figure 2. Farming systems of the Abbay basin. Source: [20].

maize and many other crops [24,28]. Studies show that it is able to simulate the canopy cover (CC), biomass development and grain yield of different maize cultivars grown under varying water availability conditions [28]. This lead to the establishment of conservative parameters for the crop, which were used by Heng et al. [27] to validate the model's performance and robustness under local conditions. Heng et al. [27] compared simulated parameters including canopy development, biomass accumulation, grain yield, evapotranspiration (ET) and water use efficiency (WUE) against their corresponding field measurements under a wide range of environments including rainfed and irrigated conditions. In the same way, this study used the conservative parameters established by Hsiao et al. [28] and validated the model under local conditions.

\subsubsection{Validation of the Model}

A range of statistical methods and visual techniques can be used to assess the goodness-of-fit of a given model and to compare the performance of a suite of models, based on the specific context of the problem [29]. In this study, due to lack of measured data, the model was validated for grain yield only; using data from research stations in and around the basin. The research stations applied the recommended rates of nitrogen and phosphorus, which varied from station to station, and this was considered as near optimal since micronutrients were not applied. Retaining the conservative parameters [28], planting dates, seeding rates, and cultivar growth characteristics (days to flowering and days to maturity) for each site were used to estimate grain yield for 17 locations and year combinations in the maize based farming system. The model output was compared with the measured grain yield data obtained from the research stations [30,31]. Combined graphical and statistical approaches were followed for the validation as suggested by Bellocchi et al. [32]. Yang et al. [33] argued that any of the Relative Root Mean Square Error (RM$\mathrm{SE}$ ), coefficient of efficiency (E), mean absolute error (MAE) and paired t-test could lead to the same conclusion. Consequently, this study used RMSE and E (Equa- 
tions 2 and 3) to examine the robustness of the model,

$$
\operatorname{RRMSE}=\left(\frac{1}{N} \sum_{i=1}^{n}\left(\frac{\mathrm{E}-\mathrm{O}}{\mathrm{O}}\right)^{2}\right)^{1 / 2}
$$

and [34] (Equation 3)

$$
\mathrm{E}=1-\frac{\sum_{i=1}^{N}\left(\mathrm{O}_{i}-\mathrm{E}_{i}\right)^{2}}{\sum_{i=1}^{N}\left(\mathrm{O}_{i}-\overline{\mathrm{O}}\right)^{2}}
$$

where $\mathrm{E}$ and $\mathrm{O}$ are the estimated and observed yield $\left(\right.$ ton $\cdot \mathrm{ha}^{-1}$ ), respectively, and $\mathrm{N}$ and $\overline{\mathrm{O}}$ are the number of observations and the mean of the measured yield $\left(\right.$ ton $\left.\cdot \mathrm{ha}^{-1}\right)$ in that order.

The RRMSE represents a measure of the mean deviation between observed and simulated values, which indicates the absolute model uncertainty [27], where as the coefficient of efficiency (E) shows how much the overall deviation between observed and simulated values depart from the overall deviation between observed values $(\mathrm{O} i)$ and their mean value $(\overline{\mathrm{O}})$. The value of $\mathrm{E}$ can range from $-\infty$ to +1 , and the model estimation efficiency increases as E gets closer to +1 [27].

\subsection{Simulating Crop Yield and Water Balance}

For brevity, the maize based farming system was considered as a huge homogenous field, so that the input data could be averaged over the whole area. Thus, ten years and seven locations (Figure 3) average weather data was used together with soil profile data averaged over the locations.

\subsubsection{Simulating Crop Yield}

While the conservative crop parameters were retained, the planting date, seeding rate and days to flowering and maturity were set based on the data from the research centers. Three soil fertility scenarios were considered including:

1) Poor-representing the traditional no fertilizer use;

2) Near optimal-representing the use of the recommended rates of nitrogen and phosphorus fertilizers and;

3) Non-limiting - representing the use of the recommended rate of both fertilizers together with the other necessary macro and micronutrients as well as treatment of other limiting factors such as soil acidity.

The soil profile data representing the Nitisols in the area was obtained from the basin master plan study document [25]. Average planting date (June 2) which corresponds with the date on which the rainfall in five successive days was at least $40 \mathrm{~mm}$ was considered. As the moisture content at planting was not known, the simulation was run from 1 January, when permanent wilting point could be assumed.

\section{RESULTS AND DISCUSSION}

\subsection{Model Validation}

AquaCrop was developed to predict crop productivity as a function of water availability under varying soil fertility conditions. In the upper part of the Blue Nile basin, the model revealed that the rainfall at all the sites considered for validation was adequate to grow maize without significant sign of moisture stress throughout the growing stages. The graphic presentation shows that the model simulation results do not perfectly match with the measured grain yield. The estimates are inconsistently higher or lower than the measured for all locations and years (Figure 4). However, the RRMSE percentage was

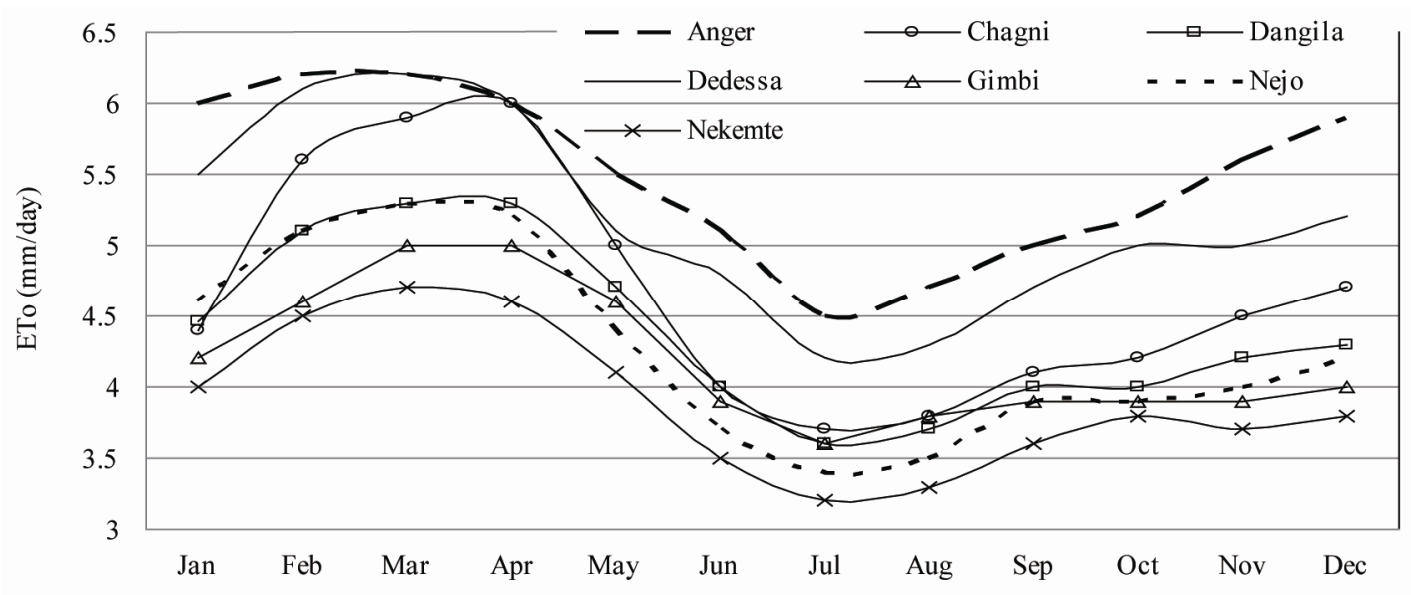

Figure 3. Average monthly reference evapotranspiration (ETo) of the weather stations used for simulation. 


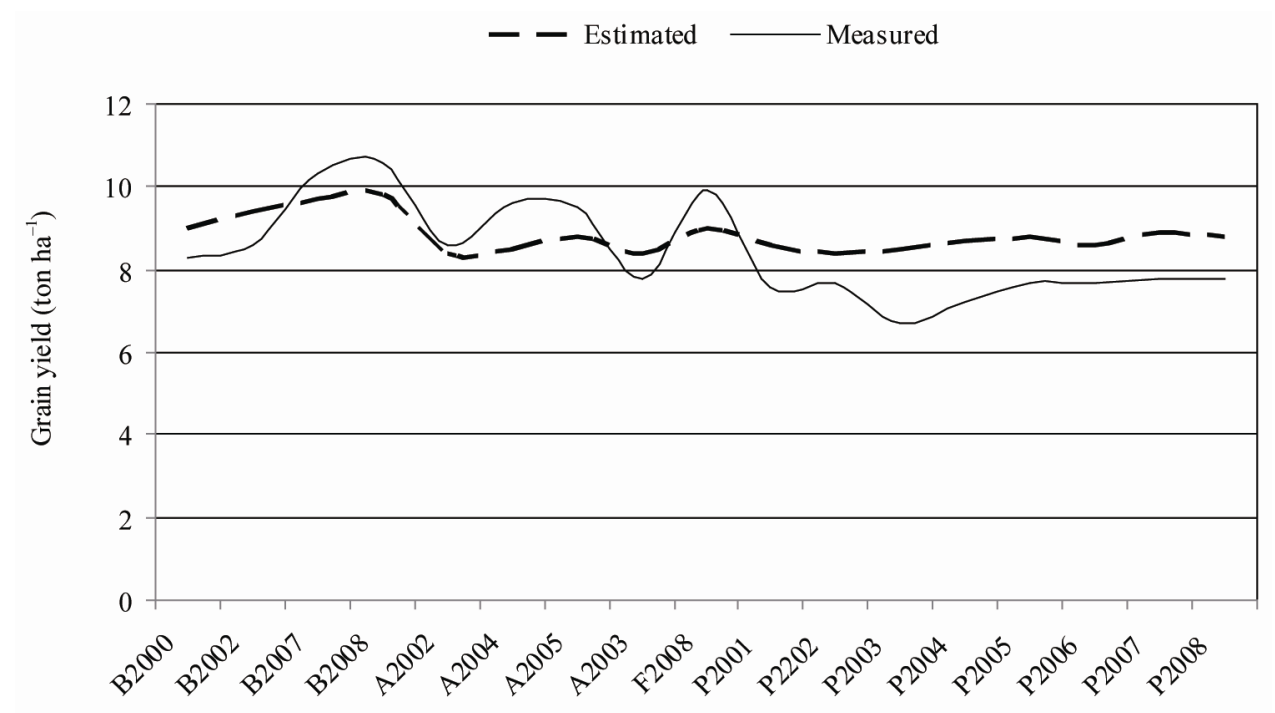

A, B, F, and P represent Adet, Bako, Fogera and Pawe, respectively and the numbers indicate the years

Figure 4. Estimated and measured grain yield of maize under near optimal soil fertility conditions.

low $(8.1 \%)$ and the model efficiency (E) was 0.98 , which is very close to +1 , indicating that the model is able to predict the productivity of maize grown under the conditions of the research stations where near optimal soil fertility conditions were maintained. This indicates that AquaCrop can predict the productivity of maize grown on Nitisols in the maize based farming system in the upper part of the Blue Nile basin.

\subsection{Crop Productivity and Water Balance}

\subsubsection{Crop Productivity}

The results indicate that moisture availability was not a limiting factor in the area as the predicted biomass productivity was $100 \%$ of the amount that could be produced under well-watered conditions (Table 2). This is because the area received a total of $1451 \mathrm{~mm}$ rainfall during the growing period. However, changing soil fertility level caused a considerable variation in the biomass produced such that $39 \%, 75 \%$ and $100 \%$ of the biomass yield that could be potentially achievable under well-fertilized conditions were obtained under the poor, near optimal and non-limiting soil fertility situations, respectively. Improving soil fertility enhances crop productivity by increasing canopy and root growth and development, which respectively increase photosynthesis and water and nutrients uptake by the crop.

The estimated average biomass yield increased from 7.5 to 19.3 tons $\cdot \mathrm{ha}^{-1}$ when the soil fertility level changed from poor to none limiting. Similarly, the corresponding increase for grain yield was from 2.5 to 9.2 tons $\mathrm{ha}^{-1}$. This agrees with Steduto et al. [35] who suggested that improvements in soil fertility and management of rain-
Table 2. Estimated performance of maize grown under different soil fertility status on Nitisols in Abbay basin.

\begin{tabular}{cccc}
\hline Soil fertility conditions & Poor & Near optimal & Non limiting \\
\hline Biomass (ton $\cdot \mathrm{ha}^{-1}$ ) & 7.5 & 14.3 & 19.2 \\
$\begin{array}{c}\text { Grain yield (ton } \cdot \mathrm{ha}^{-1} \text { ) } \\
\text { Biomass produced } \\
\text { (reference to well } \\
\quad \text { watered) }(\%)\end{array}$ & 2.5 & 6.4 & 9.2 \\
$\begin{array}{c}\text { Biomass produced } \\
\text { (reference to well } \\
\text { fertilized) }(\%)\end{array}$ & 39 & 100 & 100 \\
$\begin{array}{c}\text { Biomass Water } \\
\text { productivity }\left(\mathrm{kg} \cdot \mathrm{m}^{-3}\right)\end{array}$ & 5.1 & 5.3 & 5.4 \\
$\begin{array}{c}\text { Grain water } \\
\text { productivity }\left(\mathrm{kg} \cdot \mathrm{m}^{-3}\right)\end{array}$ & 1.7 & 2.4 & 2.6 \\
\hline
\end{tabular}

water to reduce evaporation and diverting more flows to transpiration might double or even quadruple crop yield. The result substantiates also the findings of Breman et al. [36] who based on model analysis and field experiments concluded that nutrient limitations set a stronger ceiling on yield than water availability for arid and semiarid regions.

In the highlands of Ethiopia, soil fertility depletion due to soil erosion, continuous cultivation and removal of nutrients in crop harvests is a priority problem that challenges crop productivity [37]. Consequently, soil fertility improvement was suggested as priority interventions for increased crop water productivity than water related interventions [38,39].

The use of hybrid seeds, applying recommended rates of nitrogen and phosphorus fertilizers, and implementing row planting as recommended by Tenaw et al. [40] can increase yield by three fold as compared to the current 
harvest. Enhancing soil fertility including all the necessary macro and micronutrients, and treating soil acidity may further augment productivity up to more than four times the current situation. This prediction is valid for the 3.03 million hectares of Nitisols $(70 \%$ of the 4.4 million hectares maize based farming systems) in the upper Blue Nile basin. Supposing that $50 \%$ of the Nitisols area is planted to hybrid maize annually, up to 9.7 million tons and 13.9 million tons of maize grain can be obtained under the near optimal and non-limiting soil fertility conditions, respectively (Figure 5).

\subsubsection{The Water Balance}

Soil fertility levels affected the water balance components, except runoff and infiltration (Table 3). On average, the area received a total of $1451 \mathrm{~mm}$ of rainfall during the growing period (June to October) out of which

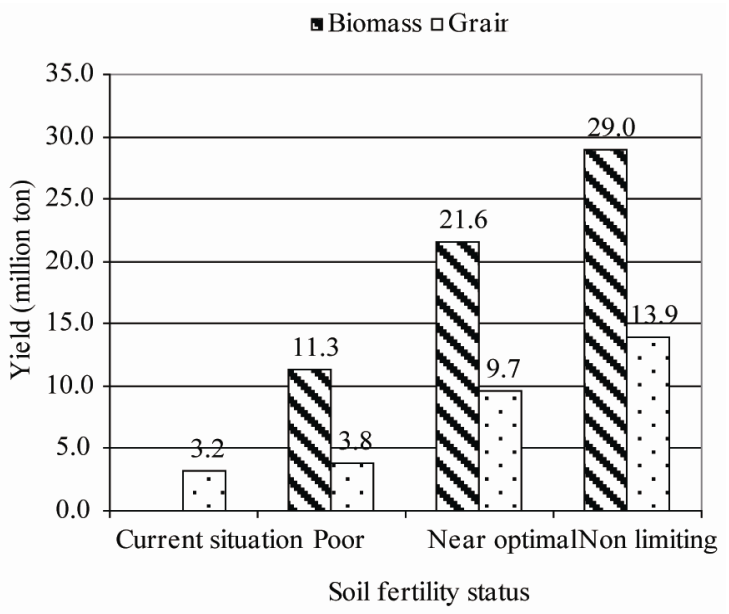

Figure 5. Biomass and grain production expected from $50 \%$ of the Nitisols area in the maize based farming systems.

Table 3. Effect of the soil fertility conditions on water balance.

\begin{tabular}{cccc}
\hline \multirow{2}{*}{$\begin{array}{c}\text { Water balance compo- } \\
\text { nents }\end{array}$} & \multicolumn{3}{c}{ Soil fertility conditions } \\
\cline { 2 - 4 } Evaporation (Ea) & 446 & 285 & 204 \\
Poor & Near optimal & Non limiting \\
$\begin{array}{c}\text { Transpiration (Ta) } \\
\text { Evapotranspiration } \\
(\mathrm{ETa})\end{array}$ & 146 & 268 & 355 \\
$\begin{array}{c}\text { Percent (Ta/ETa) } \\
\text { Runoff }\end{array}$ & 592 & 553 & 559 \\
Infiltration & 593 & 593 & 64 \\
Drainage & 276 & 311 & 393 \\
\hline
\end{tabular}

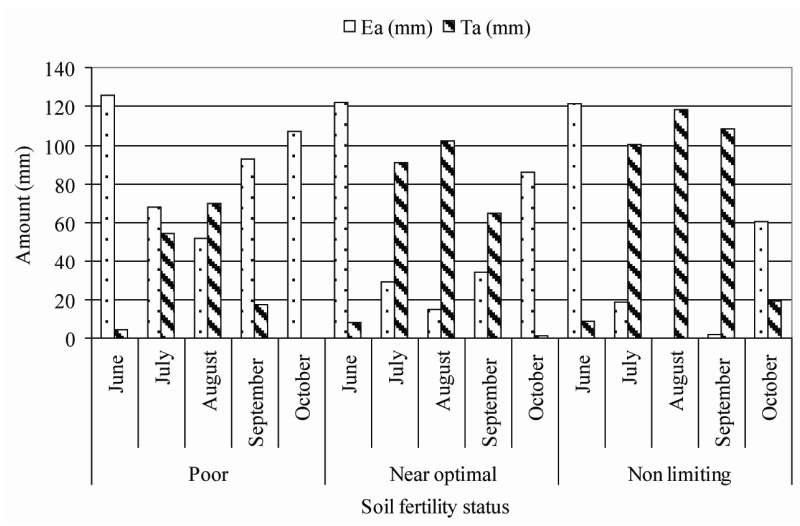

Figure 6. Effect of soil fertility on partitioning of Evapotranspiration to its components by maize

$59 \%$ infiltrated into the soil and the rest $(593 \mathrm{~mm})$ was lost as surface runoff (Annex 2). Of the infiltrated water, $276 \mathrm{~mm}, 311 \mathrm{~mm}$ and $304 \mathrm{~mm}$ drained from the rooting zone as deep percolation under poor, near optimal and non-limiting soil fertility conditions, respectively. The balance was either productively used as transpiration (Ta) or was lost as soil evaporation (Ea). Within the same soil fertility condition, the potential transpiration (Tx) and actual transpiration (Ta) were nearly the same indicating a negligible moisture stress. However, the soil fertility levels affected the balance between $\mathrm{Ea}$ and Ta (Figure 6). While the monthly Ea remained over $50 \mathrm{~mm}$ throughout the growing period under conditions of poor soil fertility, it diminished to $15 \mathrm{~mm}$ in August with near optimal and to nil in August and September when soil fertility was not limiting (Annex 1). In sharp contrast to the case with Ea, Ta increased with enhanced soil fertility conditions from a total of $146 \mathrm{~mm}$ under poor to $355 \mathrm{~mm}$ under non-limiting soil fertility conditions with a corresponding $25 \%, 48 \%$ and $64 \%$ share of the ETa. This is due to the enhanced canopy growth, which almost fully covered the soil surface by the end of August and early September under the non- limiting soil fertility conditions leading to maximum Ta and minimum Ea while a substantial part of the soil was still exposed to evaporation due to constrained canopy cover under poor soil fertility situation. Therefore, improving soil fertility decreases unproductive losses and enhances beneficial consumption or deep percolation that recharges ground water. This confirms Cooper et al. [41] who suggested that application of fertilizer might be one option to enhance water use efficiency of crops as it allows a rapid growth of the canopy that shades the soil surface, thereby reducing the proportion of the total water that is evaporated.

\subsection{Crop Water Productivity}

Improving soil fertility situation from poor to near optimal and non-limiting conditions increased grain water 
productivity by 48 and $54 \%$, respectively (Figure 7). This agrees with the findings of Stewart [42] who indicated that soil fertility is the component of a management system that affects water use efficiency and explained that a complete and balanced fertility program helps to produce a crop with roots that exploit more soil volume for water and nutrients in less time. Field and pot experiments with millet [43] and Sorghum [44] in Niger also confirmed that improved soil fertility enhances water use efficiency. In this connection, Vegh et al. [45] reported increased water use efficiency of maize with increasing phosphorus fertilizer rates.

\subsection{Potential Use of the Excess Water}

The condition of improving water management for farming systems in these high rainfall areas rests largely on managing the excess water that is lost to unproductive losses, mainly evaporation and runoff. While evaporation can be significantly converted to transpiration by enhancing crop canopy cover as discussed earlier, part of the water lost as surface runoff $(593 \mathrm{~mm})$ from the farming system can be harvested for domestic uses, livestock or to grow a second or even a third crop, depending on the type of crop to be grown and water management methods to be adopted. There are ranges of crops that can be considered, but vegetables like potato (Solanum tuberosum) and onion (Allium moly) or shallot (Alliiim ascalonicum Linnare) are among the crops widely grown during the off-season under traditional small-scale irrigation in the area. Legumes such as chickpea (Cicer arietinum) and lentil (Lens culinaries Medik) can also be grown with residual soil moisture and supplementary irrigation, and these can improve soil fertility for the next crop in addition to their contribution to the increased cropping intensity.

\section{CONCLUSIONS}

During the main rainy season, soil fertility is the major yield-limiting factor in the maize based farming system of the upper part of the Blue Nile basin. Improving soil fertility and the use of high yielding maize varieties can significantly improve water productivity by reducing evaporation loss and increasing transpiration. While this does not affect the quantity, it may improve the quality of downstream flow as the increased canopy cover can also reduce soil erosion and sediment load. The increased deep percolation may also augment water availability in the basin due to increased ground water recharge. If rain water harvesting is considered, cropping intensity can be increased. This can further enhance soil fertility if legumes are used during the dry season with supplemental irrigation. However, the feasibility of this should be confirmed through socio-economic investiga- tions before implementation.

\section{ACKNOWLEDGEMENTS}

This paper is part of the "Improved water and land management in the Ethiopian highlands and its impact on downstream stakeholders dependent on the Blue Nile" project output, supported by the Challenge Program on Water and Food. A consortium of national and international institutions implemented the project. Thanks are due to the researchers at national and regional agricultural research centers including Bako, Ambo and Adet as well as the study on livestock water productivity conducted at Fogera for providing us with the crop, soil and weather data used for validation of the model. Especial thanks to Dr. Michael Blümmel, Dr. Mosissa Worku, Dr. Yihenew G. Selassie and Mr. Gudeta Napier for allowing us use their data.

\section{REFERENCES}

[1] Rockstrom, J., Folke, C., Gordon, L., Hatibu, N., Jewitt, G., de Vries, F.P., Rwehumbiza, F., Sally, H., Savenije, H. and Schulz, R. (2004) A watershed approach to upgrade rainfed agriculture in water scarce regions through Water System Innovations: An integrated research initiative on water for food and rural livelihoods in balance with ecosystem functions. Physics and Chemistry of the Earth Parts ABC, 29, 1109-1118.

[2] Parr, J.F., Stewart, B.A., Hornick, S.B. and Singh, R.P. (1990) Improving the sustainability of dryland farming systems: A global perspective. In: Singh, R.P., Parr, J.F. and Stewart, B.A., Eds., Advances in Soil Science, Vol. 13, Dryland Agriculture Strategies for Sustainability, Springer Verlag, New York, 1-8.

[3] Rockström, J. (2001) Green water security for the food makers of tomorrow: Windows of opportunity in drought-prone savannahs. Water Science and Technology, 43, 71-78

[4] Agarwal, A. and Narain, S. (1997) Dying wisdom. Centre for Science and Environment, Thomson Press, Faridabad.

[5] Rockström, J. and Falkenmark, M. (2000) Semiarid crop production from a hydrological perspective-gap between potential and actual yields. Critical Reviews of Plant Science, 19, 319-346

[6] Bellon, M.R. (2001) Participatory research methods for technology evaluation: A manual for scientists working with farmers. Cimmyt, Mexico D.F.

[7] Wani, S.P., Sreedevi, T.K., Rockström, J. and Ramakrishna, Y.S. (2009) Rainfed agriculture-Past trends and future prospects. In: Wani, S.P., Rockström, J. and Oweis, T., Eds., Rainfed Agriculture: Unlocking the Potential, Comprehensive Assessment of Water Management in Agriculture Series, CAB International, Wallingford.

[8] Drechsel, P., Giordano, M. and Gyiele, L. (2004) Valuing nutrition in soil and water: Concepts and techniques with examples from IWMI studies in developing world. IWMI Research Paper 82, International Water Management Institute (IWMI), Sri Lanka.

[9] Benti, T., Kebede, M., Legesse, W., Mosisa, W. and Leta, T. (1997) Reflections on the successful achievements of 
hybrid maize breeding program in Ethiopia. In: Ransom, J.K., Palmer, A.F.E., Zambezi, B.T., Muduruma, Z.O., Waddington, S.R. Pixley, K.V. and Jewell, D.C., Eds., Maize Productivity Gains through Research and Technology Dissemination, Proceedings of the Fifth Eastern and Southern Africa Regional Maize Conference, Arusha, Tanzania, June 3-7 1996, 67-71.

[10] Central Statistics Authority (CSA) (2008) The federeal democratic republic of Ethiopia, central statisticsl agency, agricultural sample survey 2007/2008. Report on Area and Production of Crops. Statistical Bulletin 417, Vol. 1.

[11] Tolessa, D., Preez, C.C.D. and Ceronio, G.M. (2007) Effect of tillage system and nitrogen fertilization on yield and yield components of maize in Western Ethiopia. South African Journal of Plant and Soil, 24, 63-69.

[12] Comprehensive Assessment of Water Management in Agriculture (2007) Water for food, water for life: A comprehensive assessment of water management in agriculture. Earthscan and Colombo: International Water Management Institute, London.

[13] Tanner, C.B. and Sinclair, T.R. (1983) Efficient water use in crop production: Research or research? In: Taylor, H.M., Jordan, W.A. and Sinclair, T.R., Eds., Limitations to Efficient Water Use in Crop Production, American Society of Agronomy, Madison.

[14] Kijne, J.W., Tuong, T.P., Bennett, J., Bouman, B. and Oweis, T. (2003) The challenge program on water and food consortium. Ensuring food security via improvement in crop water productivity. Challenge Program on Water and Food: Background Papers to the Full Proposal, Sri Lanka.

[15] Molden, D. (1997) Accounting for water use and productivity. SWIM Paper 1. International Water Management Institute, Sri Lanka.

[16] Molden, D. and Sakthivadivel, R. (1999) Water accounting to assess use and productivity of water. Water Resources Development, 15, 55-71. doi:10.1080/07900629948934

[17] Teklu, E., Awulachew, S.B., Amare, H. and Aster, D. (2009) Impacts of improving water management of smallholder agriculture in the Upper Blue Nile basin. In: Awulachew, S.B., Teklu E., Smakhtin, V.K. and Fernando, A., Eds., Improved Water and Land Management in the Ethiopian Highlands: Its Impacts on Downstream Stakeholders Dependent on the Blue Nile, Intermediate Results Dissemination Workshop held at the International livestock Research Institute (ILRI), Addis Ababa, 5-6 February 2009

[18] Seleshi B.A., Denekew, A., Loulseged, M., Loiskandl, W., Ayana, M. and Alamirew, T. (2007) Water resouces and irrigation development in Ethiopia, Colombo, Sri Lanka. International Water Management Institute, Working Paper 123 .

[19] Teklu, E. and Gezahegn, A. (2003) Indigenous knowledge and practices for soil and water management in East Wollega, Ethiopia. In: Wollny, C., Deininger, A., Bhandari, N., Maass, B., Manig, W., Muuss, U., Brodbeck, F. and Howe, I., Eds., Technological and Institutional Innovations for Sustainable Rural Development, Deutscher Tropentag,

[20] Seleshi, B.A. (2010) Improved water and land management in the Ethiopian Highlands and its impact on down- stream stakeholders dependent on the Blue Nile. International Water Management Institute, CPWF Project Report, Project Number, submitted to CGIAR Challenge Program for Water and Food.

[21] Raes, D., Steduto, P., Hsiao, Th. and Fereres, E. (2009) AquaCrop-The FAO crop model for predicting yield response to water: II. Main algorithms and soft ware description. Agronomy Journal, 101, 438-447. doi:10.2134/agronj2008.0140s

[22] Steduto, P., Hsiao, T.C., Raes, D. and Fereres, E. (2009) AquaCrop-The FAO crop model to simulate yield response to water: I Concepts. Agronomy Journal, (In Press).

[23] Abayneh, E., Demeke, T. and Ashenafi, A. (2006) Soils of adet agricultural research center and its testing sites. National Soil Research Center (NSRC) Soil Survey and Land Evaluation Section, Soil Survey Internal Report

[24] Wakene, N. (2001) Assessment of important physicochemical propoerties of Nitosols under different management systems in Bako area, Western Ethiopia. M.Sc Theisis, School of Graduate Studies, Alemaya Unviersity, Ethiopia.

[25] BCEOM (1998) Abbay river basin master plan project-Phase 2: Agriculture.

[26] Doorenbos, J. and Kassam, A.H. (1979) Yield response to water. Irrigation and Drainage Paper No. 33, FAO, Rome, Italy.

[27] Heng, L.K., Hsiao, Th., Evett, S., Howell, T. and Stedut, P. (2009) Validating the FAO AquaCrop model for irrigated and water deficient field maize. Agronomy Journal, 101, 488-498. doi:10.2134/agronj2008.0029xs

[28] Hsiao, T.C., Heng, L.K., Steduto, P., Rojas-Lara, B., Raes, D. and Fereres, E. (2009) AquaCrop-Th FAO crop model to simulate yield response to water: III. Parameterization and testing for maize. Agronomy Journal, 101 448-459. doi:10.2134/agronj2008.0218s

[29] Berk, R.A., Fovell, R.G., Schoenberg, F. and Weiss, R.E. (2001) The use of statistical tools for evaluating computer simulations - an editorial essay. Climatic Change, 51, 119-130 doi:10.1023/A:1012241427060

[30] Mosissa, W. (1999) Stability of maize genotypes across locations and soil Fertility levels. M.Sc Thesis, School of Graduate Studies of Alemaya University, Alemaya, Ethiopia.

[31] Yihenew, G.S.M. (2004) Modeling of nitrogen and phosphorus fertilizer recommendations for maize (Zea mays L.) grown on Alfisols of Northwestern Ethiopia. Ph.D Dissertation, Kasetsart University, Thailand.

[32] Bellocchi, G., Mike, R., Marcello, D. and Keith, M. (2009) Validation of biophysical models: Issues and methodologies. Agronomy for Sustainable Development, 30, 109-130. doi:10.1051/agro/2009001

[33] Yang, J., Greenwood, D.J., Rowell, D.L., Wadsworth, G.A. and Burns, I.G. (2000) Statistical methods for evaluating a crop nitrogen simulation model, N-ABLE. Agricultural System, 64, 37-53. doi:10.1023/A:1012241427060

[34] Nash, J.E. and Sutcliffe, J.V. (1970) River flow forecasting through conceptual models, Part 1, A discussion of principles. Journal of Hydrology, 10, 282-290. doi:10.1016/0022-1694(70)90255-6

[35] Steduto, P., Jacob, W. K., Hanjra, M., Prem, A. and Bindraban, S. (2007) Pathways for increasing agricultural 
water productivity, water use and productivity in a river basin.

http://www.iwmi.cgiar:assessment/Water $\% 20$ for $\% 20$ Foo d\%20Water $\% 20$ for $\% 20$ Life/Chapters/Chapter $\% 207 \% 20$ Water\%20Productivity.pdf

[36] Breman, H., Groot, J.J.R. and van Keulen, H. (2001) Resource limitations in Sahelian agriculture. Global Environmental Change, 11, 59-68. doi:10.1016/S0959-3780(00)00045-5

[37] Smaling, E.M.A., Nandwa, S.M. and Janssen, B.H. (1997) Soil fertility is at stake. In: SSSA, Eds., Replenishing Soil Fertility in Africa, Soil Science Society of America Special Publication, Madison, 47-61.

[38] Aregawi, B. (1989) Research on multipurpose tree species in Ethiopia. Proceedings of the IAR/ICP, AF National Agroforestry Workshop, Awasa, 14-18 November 1988, 29-32.

[39] ICRAF (1990) Agroforestry: Potentials and research needs for the Ethiopian Highlands No. 21. In: Hoekstra, D.A., Torquebiau, E. and Bishaw, B., Eds., ICRAF, Nairobi.

[40] Tenaw, W., Waga, M., Beirtukan, M., Tolessa, D., Tesfa, B., Berhanu, A., Hussein, M.A.and Tewodros, M. (2001) Development of appropriate cultural practices for maize production in Ethiopia, In: Mandefro, N., Tanner, D. and Twumasi-Afriyie, S., Eds., Enhancing the Contribution of Maize to Food Security in Ethiopia, Proceedings of the Second National Maize Workshop of Ethiopia, Addis Ababa, 12-16 November 2001.

[41] Cooper, P.J.M., Gregory, P.J., Tully, D. and Harris, H.C. (1987) Improving water use efficiency of annual crops in the rainfed farming systems of West Asia and North Africa. Experimental Agriculture, 23, 113-158. doi:10.1017/S001447970001694X

[42] Stewart, W.M. (2001) Balanced fertilization increases water use efficiency, news and views. The Potash and Phosphate Institute (PPI) and the Potash \& Phosphate Institute of Canada (PPIC).

[43] Gregory, P.J. (1988) Plant and management factors affecting the water use efficiency of dryland crops. In: Unger, P.W., et al., Eds., Challenges in Dryland Agriculture: A Global Perspective, Texas A \& M University Press, College Station, 171-175.

[44] Hundekar S.T., Badanur, V.P. and Saranagamath, P.A. (1999) Effect of crop residues in combination with fertilizers on soil properties and sorghum yield. Fertilizer News, 44, 59-63.

[45] Vegh, K.R., Szundy T., Rajkai K. and Tischner T. (1998) Roots, phosphorus uptake and water use efficiency of maize genotypes. Acta Agronomica Hungarica, 46, 3543. 